\title{
Sediment budgets for a sediment-laden river: the lower Wei River in the period 1960-1990
}

\author{
Wenwei Shao, ${ }^{1,2}$ Changxing Shi, ${ }^{1 *}$ Xiaoli Fan, ${ }^{1,2}$ Yuanyuan Zhou ${ }^{1,2}$ and Jianbin Bai ${ }^{1,2}$ \\ ${ }^{1}$ Key Laboratory of Water Cycle and Related Land Surface Processes, Institute of Geographic Sciences and Natural Resources \\ Research, CAS, Beijing 100101, China \\ 2 University of Chinese Academy of Sciences, Beijing 100049, China
}

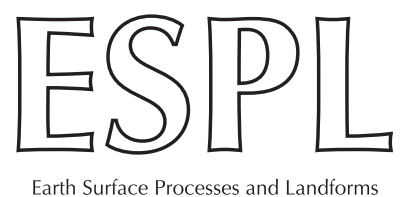

ABSTRACT: Fluvial sediment delivery is the main form of sediment transfer from the land to the sea, but this process is currently undergoing significant variations due to the alteration of catchment and base level controls related to climate change and human activities, especially the widespread construction of dams. Using the lower Wei River as an example and an integrated approach, this study investigates the variation of fluvial sediment delivery, as well as the connectivity under the effects of both controls. Based on hydrological records and channel cross-section surveys, sediment budgets were constructed for two periods (1960-1970, 1970-1990) after the dam was closed in 1960. In the period 1960-1969, due to the elevated base level (327.2 $\pm 1.62 \mathrm{~m})$ caused by the dam, the aggradation rate was $0.451 \times 10^{8} \mathrm{tyr}^{-1}$ in the channel and $0.716 \times 10^{8} \mathrm{tyr}^{-1}$ on the floodplain, indicating that the positive lateral connectivity between these locations was enhanced. As a consequence, serious sediment storage resulted in a sediment delivery ratio (SDR) that was smaller than that occurring before 1960. In the period 1970-1990, sweeping soil and water conservation (SWC) measures were implemented, resulting in a reduction of the connectivity between the trunk and tributaries, and a decrease of $\sim 31 \%$ in the mean sediment input. In addition, together with the base level fluctuation in the range of $327.47 \pm 0.49 \mathrm{~m}$, the annual variation in sediment storage was primarily dependent on the water-sediment regime affected by the SWC. The negative lateral connectivity was enhanced between the channel and floodplain via bank erosion. Consequently, the aggradation rate was reduced by $89 \%$ on the floodplain and by $96 \%$ in the channel. Sediment output continued to decrease primarily due to the SWC practices and climate changes in this period, whereas the SDR increased due to the enhanced longitudinal connectivity between the upstream and downstream. Copyright (C) 2014 John Wiley \& Sons, Ltd.

KEYWORDS: sediment budget; sediment delivery; catchment control; base level control; lower Wei River

\section{Introduction}

Fluvial sediment delivery is the main form of sediment transfer from the land to the sea (Syvitski et al., 2003, 2005; Walling, 2006). This process plays an important role in the global geochemical cycle because it functions as a 'conveyor belt' to deliver sediment or sediment-associated particles $(C, N$, and P) from sources to sinks (Walling and Fang, 2003; Fryirs, 2013; Ran et al., 2014). Fluvial sediment delivery is accompanied by negative ecological and environmental effects, i.e. soil losses, natural landscape degradation, increased flood risks with channel aggradation, and water quality deterioration (Tarras-Wahlberg and Lane, 2003; Beven et al., 2005; Evans and Warburton, 2005). Furthermore, because of the impacts of global climate change and anthropogenic activities, the environment and the process of the sediment delivery are simultaneously changed to a certain extent as a function of the intensity and type of modifications (Higgitt and Lu, 2001; Lane et al, 2007; Owens et al., 2010). Thus, although it has been an academic research topic for many years, an improved understanding of fluvial sediment delivery is undoubtedly critical (Walling, 1983; Fryirs, 2013).
One issue concerning fluvial sediment delivery is the relationship between fluvial sediment delivery and its controls, which may be classified into catchment control (upstream control) and base level control (downstream control) (Mackin, 1948). Catchment control includes the environmental and geomorphological factors that contribute to the sediment dynamics in catchments, i.e.climate condition, biotic factors (e.g. vegetation), topography and channel slope, soil characteristics, hydrological processes (e.g. flood duration), and human modifications (e.g. dams, soil erosion controls) (Trimble, 1999; Higgitt and Lu, 2001; Darke and Megonigal, 2003; Syvitski et al., 2005; Holliday et al., 2008; Slattery and Phillips, 2011). The base level is usually considered as the surfaces of seas, lakes, or the confluences to which fluvial system erosion proceeds. The change of base level could be affected by river capture, human activities, and climate change (Schumm, 1993; Mather, 2000; Florsheim et al., 2001). Erosion or aggradation occurs when the base level falls or rises and thus reduces or increases the sediment residence time (Florsheim et al., 2001). In most cases, the responses of fluvial sediment delivery to these controls are complicated and nonlinear. For example, in a study of a small coastal plain watershed in 
North Carolina, USA, although the storm intensity was low in early spring, Lecce et al. (2006) showed that the sediment load was still significant because of the low vegetation coverage, which was favorable to soil erosion. Another classical study conducted in the Coon Creek catchment, USA was reported by Trimble (1999). Although the SWC effectively controlled the soil erosion, it was found that the sediment yield of the catchment was relatively steady compared with that in the period before the implementation of SWC. Unfortunately, most studies only focus on the catchment control, and the possible reasons for this focus are that: (1) changes in catchment control are obvious; and (2) the base level is mostly static for most catchments. When the base level control is dynamic as well, it is necessary to investigate the behaviors of sediment delivery that are impacted by the two types of controls. Few studies have discussed this issue. For instance, Shi (2005) isolated the effect of the base level and catchment controls on continuous siltation in the Yellow River. Frings et al. (2014) also distinguished the contributions of base level, hydrological, and human controls to sediment dynamics in the Rhine River of Europe. However, the literature appears to lack detailed information associated with the components of a sediment delivery system under the influences of both controls, which is critical to the knowledge of sediment delivery.

In recent years, the concept of sediment connectivity has caught the attention of many scholars. Sediment connectivity is defined as the degree of coupling, i.e. the combined effect of lateral (hillslope to channel) and longitudinal (from one river reach to another) linkages between system components (Heckmann and Schwanghart, 2013). Previous studies have been carried out on the factors that influence sediment connectivity, the extents of their impacts, the resulting changes in the processes of sediment conveyance (Fryirs et al., 2007), the types of sediment connectivity, and methods for quantifying sediment connectivity (Hooke, 2003; Jain and Tandon, 2010). In addition, the relationships of sediment connectivity with scale effects in sediment conveyance and with the sediment delivery ratio were investigated by certain studies (Delmas et al., 2012; López-Tarazón et al., 2012). It was demonstrated that sediment connectivity provides a conceptual framework for studying the structure and characteristics of fluvial sediment delivery systems, the dynamics of sediment delivery, and the response of the systems to external interference.

In this paper, we investigate the variation of fluvial sediment delivery as well as sediment connectivity under the effects of both catchment and base level controls using an integrated approach and taking the lower Wei River as an example. The lower Wei River is a typical sediment-laden alluvial river. Human activities and climate change have altered both the upstream and downstream controls of the river during the past 50 years. Thus, the lower Wei River provides a good example for examining the dynamic changes in the sediment delivery of river reaches via modifications of both catchment and base level controls. To investigate quantitatively the dynamic changes of sediment delivery of the river reaches, we used the sediment budget method, which is an effective organizing framework for representing the key components of a sediment delivery system (Walling and Collins, 2008; Trimble, 2009). Using the established sediment budgets in combination with an analysis of the detailed spatial and temporal variations of the siltation in the river reach, we discuss: (1) the spatial and temporal dynamics of the sediment delivery; (2) the dominant control on sediment delivery in different periods; and (3) the changes in sediment connectivity between the main sediment delivery components of the lower Wei River.

\section{Study Area}

\section{Drainage basin characteristics}

The Wei River basin is located in the mid-west area of China. With a drainage area of $134767 \mathrm{~km}^{2}$ and a total length of $818 \mathrm{~km}$, this river ranks as the largest tributary of the Yellow River (Figure 1(A)) and covers a portion of the Loess Plateau in the north as well as the north slope of Qinling Ranges in the south (Figure 1(B)). The Wei River originates from Niaoshu Mountain in Gansu Province and flows eastward, falling from $3495 \mathrm{~m}$ a.s.l. at the headwater to only $329 \mathrm{~m}$ a.s.l. at the basin outlet. The catchment experiences a monsoon climate with a mean annual precipitation of $600-800 \mathrm{~mm}$ and an average annual potential evaporation of 1200-1400 mm. Approximately $60 \%$ of the annual precipitation occurs in the form of rainstorms during the wet seasons from July to October.

The lower Wei River flows within the Wei He Graben in which Cenozoic deposits range between 2000 and $7000 \mathrm{~m}$ in thickness and the thickness of Quaternary strata has a higher estimate of $1200 \mathrm{~m}$ (Sun and $\mathrm{Xu}, 2007$ ). The wide floodplains of the river in the graben basin are quite suitable for agriculture and have been referred to as the ' $800 \mathrm{li}$ (a Chinese unit for $500 \mathrm{~m}$ ) fertile Qin valley' for a long time (Wang et al., 2007).

The study area consists of a $208 \mathrm{~km}$ reach extending from Xianyang city to the Tongguan gauging station, where the Wei River flows into the middle Yellow River (Figure 1(C)). Three types of channel pattern are recognized in the reach (GSWR, 1983): (1) between the Xianyang gauging station (CS37) and the mouth of the Jing River (CS27) is a wandering section with a stream length of $37 \mathrm{~km}$, a slope of 0.0063 , and a channel width of $300-2000 \mathrm{~m}$ in low-flow periods; (2) between the mouth of the Jing River (CS27) and the mouth of the Chi River (CS15) is the transitional section that varies from wandering to meandering with a stream length of $63 \mathrm{~km}$, a slope of 0.0046 , and a channel width of $200-800 \mathrm{~m}$ in low-flow periods; and (3) downstream of the mouth of the Chi River is a meandering section with a length of $108 \mathrm{~km}$, a slope of $0.001-0.0018$, and a channel width of 150-500 $\mathrm{m}$ in low-flow periods.

On the north side of the study reach, the Jing River and the Beiluo River are the two main tributaries that drain the Loess Plateau. The plateau features serious soil erosion, of which gully erosion accounts for more than $80 \%$ (Shi and Shao, 2000). Most research in this area has shown that the sediment delivery ratio (SDR) of the Loess Plateau was close to $100 \%$ under natural conditions with the erosion modulus estimated between 4000 and $10000 \mathrm{t} \mathrm{km}^{-2} \mathrm{yr}^{-1}$ (Jiao et al., 2004). On the south side are mountain tributaries with a high gradient and a comparatively low sediment load because of the high vegetation coverage and shortage of loess.

The flood period of the Wei River lasts from July to October (Figure 2) with a recorded maximum peak discharge of $7660 \mathrm{~m}^{3} \mathrm{~s}^{-1}$ at the Huaxian gauging station in August 1954. The mean annual water discharge is $8.77 \times 10^{9} \mathrm{~m}^{3}$, and the mean annual suspended sediment load (SSL) is $4.12 \times 10^{8} \mathrm{t}$ based on the records at the Huaxian gauging station. The discharge in flood periods represents nearly $58.9 \%$ of the annual total and approximately $90 \%$ for the suspended sediment load.

\section{Human influence}

The lower Wei River was considered close to grade prior to 1960 (GSWR, 1983); however, human modifications have significantly changed the sediment delivery system during the last 50 years. One of the main modifications is the construction 


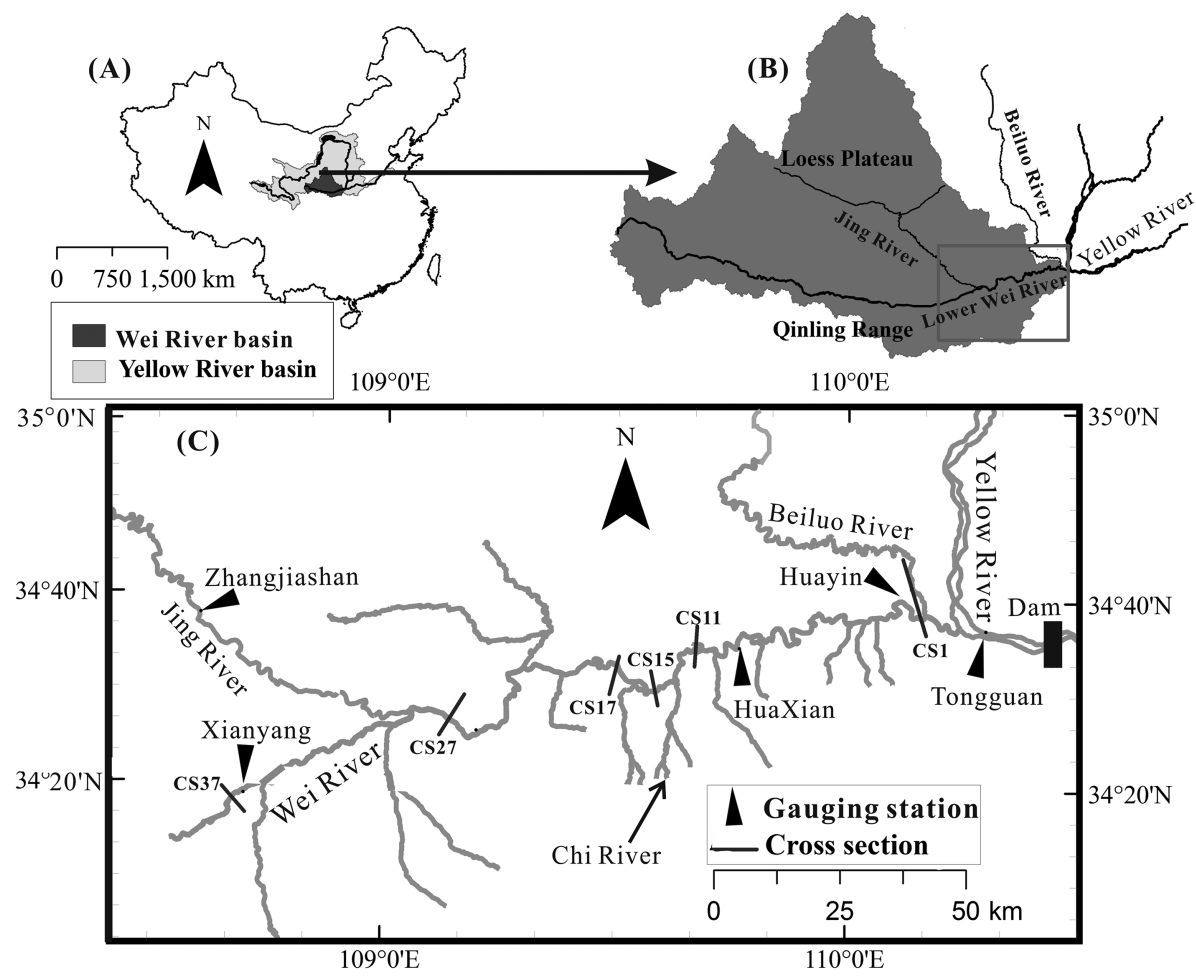

Figure 1. Map of the location of (A) the Wei River basin in the Yellow River basin, (B) the Wei River basin, (C) the lower Wei River.

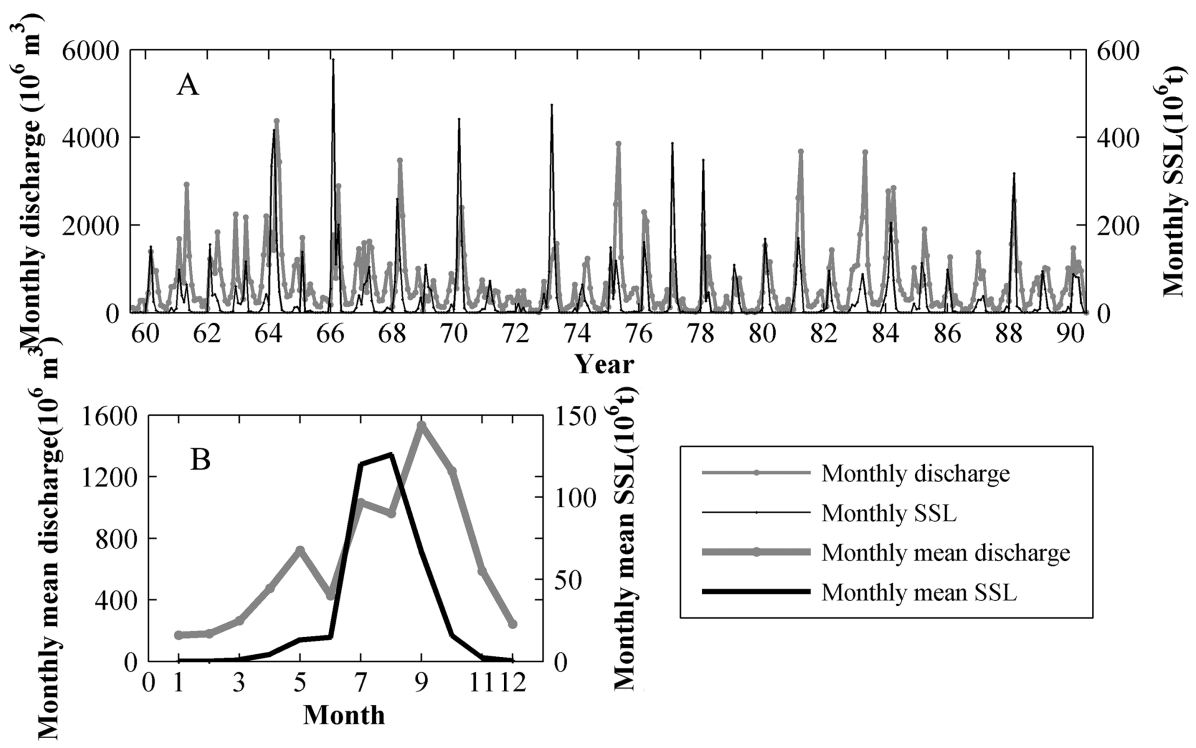

Figure 2. (A) Monthly discharge and suspended sediment load at the Huaxian Station in 1960-1990; (B) mean discharge and SSL for each month in the period 1960-1990, illustrating that the sediment load reached a maximum in July and August and water discharge reached a maximum in September and November.

of Sanmenxia Dam, and the other is the SWC measures that have been enacted.

The principal impact factor is the Sanmenxia Dam located downstream of the infall of the Wei River to the middle Yellow River (Figure 1(C)). The Sanmenxia Dam has undergone three different operational modes since impoundment in March 1960 (Figure 3). The first mode is 'storage', which was employed from September 1960 to March 1962, during which the dam functioned as a barrier to store all sediment input year round. Severe sediment deposition and flood disasters occurred in the lower Wei River, which led to a change in the operational mode and the first reconstruction of the dam (Wang et al., 2005). The second operational mode is referred to as 'flood detention' and was implemented from March 1962 to November 1973 for the purpose of detaining floods and sluicing sediment (Wang et al., 2005). To further increase the capacity of the sediment sluicing, the second reconstruction was begun in December 1969 and was completed in October 1971. During this time, the dam water level was significantly reduced from $307.72 \mathrm{~m}$ to $299.81 \mathrm{~m}$ after 1969 and was maintained at approximately $305 \mathrm{~m}$ after 1973. The third operational mode is described as 'controlled release' and was put into use after November 1973; this mode involved release of water and sediment during the flood seasons and detainment in low flow periods (Wang et al., 2005, 2007). All three operational modes led to fluctuation of the Tongguan elevation, 


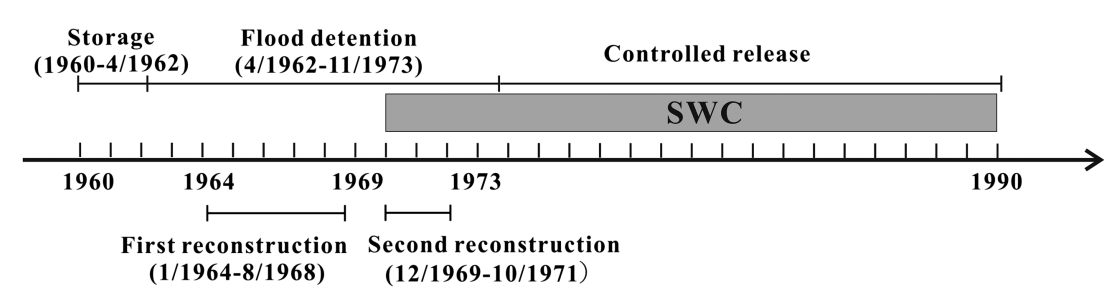

Figure 3. Timetable of operational modes and reconstructions of the Sanmenxia Dam together with soil and water conservation measures.

which is defined as the water level at the discharge of $1000 \mathrm{~m}^{3} \mathrm{~s}^{-1}$ at the Tongguan station and is considered as the base level of the Wei River (Wu et al., 2004).

The SWC measures have been widely implemented in the river basin since 1970 (Figure 3) and include hillslope measures and gully measures. The hillslope measures primarily include terracing, forestation, and grass sowing, which are used to control the hillslope erosion on the loess tablelands, ridges, and mounds. Gully measures primarily include sediment check dams used to control gravitational erosion and detain sediment. The check dam has been demonstrated as the most effective approach to harnessing soil erosion in the Loess Plateau. A total of $55 \mathrm{~km}^{2}$ of silted lands were created behind check dams, and $5167 \mathrm{~km}^{2}$ of level terraces, $6397 \mathrm{~km}^{2}$ of woodland, and $1788 \mathrm{~km}^{2}$ of grassland were built up until 1990 (Wang et al., 1994).

\section{Methods and Data}

The sediment budget method is used to represent the components of the sediment delivery system of the lower Wei River. Generally, a sediment budget reflects the balance among the sediment source, sediment storage, and output and can be described by the following equation (Slaymaker, 2003):

$$
I_{S}+\Delta S_{S}=O_{S}
$$

where $I_{S}, \Delta S_{S}$, and $O_{S}$ are the sediment input, changes in sediment storage, and sediment output, respectively. Each of the items in Equation (1) can be decomposed into the components listed in Table I, which also provides data sources for estimating the components.

In this paper, we chose the year 1969 as the dividing point of the study period to establish two budgets (1960-1969 and 1970-1990). The reasons for this division are that: (1) the dam water level was significantly reduced after 1969, as mentioned previously; (2) the capacity of the sluicing sediment was greatly enhanced after 1969; and (3) the SWC measures have been widely implemented since 1970 .

Table I. Sediment budget components and their data sources

\begin{tabular}{|c|c|}
\hline Sediment budget items & Data source \\
\hline \multicolumn{2}{|l|}{ Sediment input } \\
\hline Upstream & $\begin{array}{l}\text { Xianyang hydrological } \\
\text { station }\left(\mathrm{YRCC}^{*}\right)\end{array}$ \\
\hline Tributary (Jing River) & $\begin{array}{l}\text { Zhangjiashan hydrological } \\
\text { station (YRCC) }\end{array}$ \\
\hline \multicolumn{2}{|l|}{ Sediment storage } \\
\hline Channel storage & $\begin{array}{l}\text { Cross section } \\
\text { measurement (YRCC) }\end{array}$ \\
\hline \multicolumn{2}{|l|}{ Floodplain storage } \\
\hline \multicolumn{2}{|l|}{ Sediment output } \\
\hline $\begin{array}{l}\text { Sediment output at } \\
\text { the catchment outlet }\end{array}$ & $\begin{array}{l}\text { Estimated through sediment } \\
\text { input minus the storage }\end{array}$ \\
\hline
\end{tabular}

*YRCC - the Yellow River Conservancy Commission

\section{Sediment input}

The reaches located upstream of the Xianyang station and the Jing River are the two main sediment and water sources of the lower Wei River. The Beiluo River was not listed in the budgets because it drains into the lower Wei River below CS1, the outlet of the study reach. The discharge and SSL are recorded at the Xianyang gauging station and the Zhangjiashan gauging station, which is the lowest on the trunk of the Jing River (Figure 1(C)). The bed load is neglected because it accounts for only approximately $1 \%$ of the total sediment load (GSWR, 1983). The rating curve method was used to estimate the daily water discharge and daily suspended sediment concentration (SSC) based on the operational manuals and state standards issued by the Chinese Ministry of Water Resource (Xu, 2000). The SSL was calculated as the product of SSC and the discharge. The uncertainty associated with the SSL was estimated using the Monte Carlo method (Tarras-Wahlberg and Lane, 2003). The rank-based Mann-Kendall statistical trend analysis was applied to the data series to disclose the trends of water discharge and sediment load during the period 1960-1990. The confidence interval is set at 95\%, and a detailed introduction of Mann-Kendall trend analysis technique is given by Zhang et al. (2006).

\section{Channel and floodplain storage}

Thirty-seven cross-sections with a mean spatial interval of approximately $5800 \mathrm{~m}$ have been established by YRCC since 1960 to monitor the changes in the channel and floodplain, and they are referred to as cross-section 1 (CS1), CS2, etc. up to CS37 spanning from the river mouth to the Xianyang station (Figure $1(\mathrm{C})$ ). All cross-sections were surveyed twice each year, before and after the flood seasons. A sounding rod or lead with an error of $0.08 \mathrm{~m}$ was used for the bathymetric surveys. Floodplains were measured by optical level surveys with a vertical error of $0.02 \mathrm{~m}$ and a horizontal error of $0.06 \mathrm{~m}$. Although sediment samples were collected both in the channel and on the floodplain, detailed information on the bulk density was unavailable. To transform the volume of sediment deposition/ erosion into weight, this study uses the value of $1.4 \mathrm{~g} \mathrm{~cm}^{-3}$ recommend by Cheng et al. (1993).

The channel defined in this paper includes the channel bed and the point bars, and the floodplain is defined as the portion of the cross-sections on both sides of the channel. Points that divide the cross-sections into the channel and floodplain were chosen manually based on the geomorphic characterization. The difference in the channel capacity $\left(\mathrm{m}^{3}\right)$ of a reach between two measurements is considered as the net change of sediment storage. The following equations are used to calculate the sediment storage:

$$
V_{i}=\frac{S_{1 i}+S_{2 i}}{2} L, i=1,2,3 \cdots, n
$$




$$
\Delta V=V_{i+1}-V_{i}, i=1,2,3 \cdots, n
$$

where $S_{1 \mathrm{i}}\left(\mathrm{m}^{2}\right)$ and $S_{2 \mathrm{i}}\left(\mathrm{m}^{2}\right)$ are the cross-sectional areas of two adjacent cross-sections indicated by subscripts 1 and 2 in the $i^{\text {th }}$ measurements respectively, $L(\mathrm{~m})$ is the distance between the middle points of the cross-sections, $V_{i}\left(\mathrm{~m}^{3}\right)$ and $V_{i+1}\left(\mathrm{~m}^{3}\right)$ are the channel capacity of the reach between two crosssections in the $i$ th and $i+i$ th measurements, respectively, and $\Delta V\left(\mathrm{~m}^{3}\right)$ is the net change of channel capacity between the two measurements. A negative value of $\Delta V$ represents erosion, and a positive value represents sediment storage. The sediment storage can be estimated by multiplying the $\Delta V$ by a mean dry bulk density of $1.4 \times 10^{3} \mathrm{~kg} \mathrm{~m}^{-3}$. The error propagation method given in Reid et al. (2007) is used to estimate the uncertainty of volume changes for both the channel and floodplain.

\section{Sediment output}

The sediment output through CS1 is estimated from the sediment input and the sediment storage based on Equation (1). Although the Huayin gauging station, which is located $5000 \mathrm{~m}$ upstream from CS1, can be considered as the outlet of the study reach, there are no consecutive records of water discharge and sediment load at this station. The water discharge and sediment load at this station were gauged year round in the period 1962-1966, were gauged only in flood seasons in the period 1976-1990, and were not gauged in the period 1967-1975. We used the available records at this station to examine the estimated sediment output in this paper.

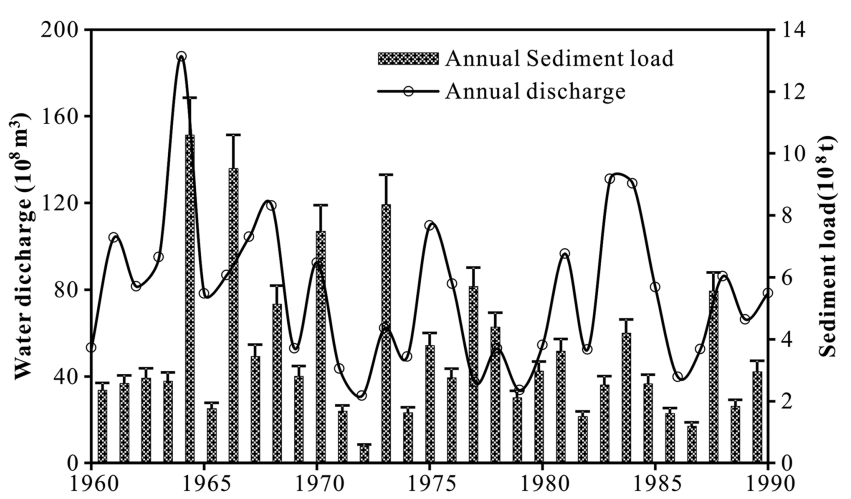

Figure 4. Sum of the annual water discharge and sum of the annual suspended sediment load recorded at the Xianyang and Zhangjiashan gauging stations in the period 1960-1990 (uncertainties for the suspended sediment load are shown by error bars).

\section{Results}

\section{Sediment input}

Hydrologic measurements indicated that the sediment load was mostly transported from the Jing River, whereas water discharge originated primarily from the upper reaches. In the period from 1960 to 1990 , the mean water discharge at the Xianyang station was $48.64 \times 10^{8} \mathrm{~m}^{3} \mathrm{yr}^{-1}$, which carried a mean sediment load of $1.39 \times 10^{8} \mathrm{tyr}^{-1}$, whereas the Zhangjiashan station recorded a water discharge of $14.86 \times 10^{8} \mathrm{~m}^{3} \mathrm{yr}^{-1}$ and a sediment load of $2.34 \times 10^{8} \mathrm{tyr}^{-1}$. The mean annual water and sediment inputs into the study reach from the upper reaches of the mainstream and from the Jing River were $63.5 \times 10^{8} \mathrm{~m}^{3} \mathrm{yr}^{-1}$ and $3.73 \times 10^{8} \mathrm{tyr}^{-1}$, respectively, of which the water discharge from the former sources accounted for $77 \%$ of the total, but its sediment load was only $37 \%$ of the total.

Figures 4 and 5 showed that both the water discharge and sediment load presented a decreasing trend in the period from 1960 to 1990 , but this trend is not statistically significant according to the Mann-Kendall test $(-1.96<$ UF $<1.96)$. The Mann-Kendall test showed that the water discharge exhibited an increasing trend during the period 1960-1970 and a decreasing trend in 1971-1990 (Figure 5(a)). The sediment load showed an increasing trend in 1960-1971 but had a general decreasing trend in the period 1972-1990 (Figure 5(b)).

\section{Sediment storage in the channel}

Temporal variations of the channel storage

Sediment storage in the channel is derived using Equations (2) and (3) and is illustrated in Figure 6(A). In the period 1960-1990, a net volume of $3.13 \pm 0.03 \times 10^{8} \mathrm{~m}^{3}$ of sediment with an average of $0.1 \times 10^{8} \mathrm{~m}^{3} \mathrm{yr}^{-1}$ was trapped in the channel, suggesting that the channel acted as a sediment sink.

According to the cumulative sediment storage in the channel (Figure 6(B)), the sedimentation process in the period 1960-1969 was quite different from that in the period 1970-1990. During the first period, the sediment storage in the channel increased rapidly at a rate of $0.32 \times 10^{8} \mathrm{~m}^{3} \mathrm{yr}^{-1}$ with a total storage of $2.9 \pm 0.02 \times 10^{8} \mathrm{~m}^{3}$, which accounted for $92.5 \%$ of the total in 1960-1990, and most of the sediment was trapped in the period 1966-1968. The second period featured alternate scouring and filling with a small volume of sedimentation of only $0.24 \pm 0.03 \times 10^{8} \mathrm{~m}^{3}$ at a rate of $0.01 \times 10^{8} \mathrm{~m}^{3} \mathrm{yr}^{-1}$.

Spatial variations of the channel storage

The sediment storage in the channel was calculated for each reach defined by two adjacent cross-sections (Figure $7(\mathrm{~A})$ ).
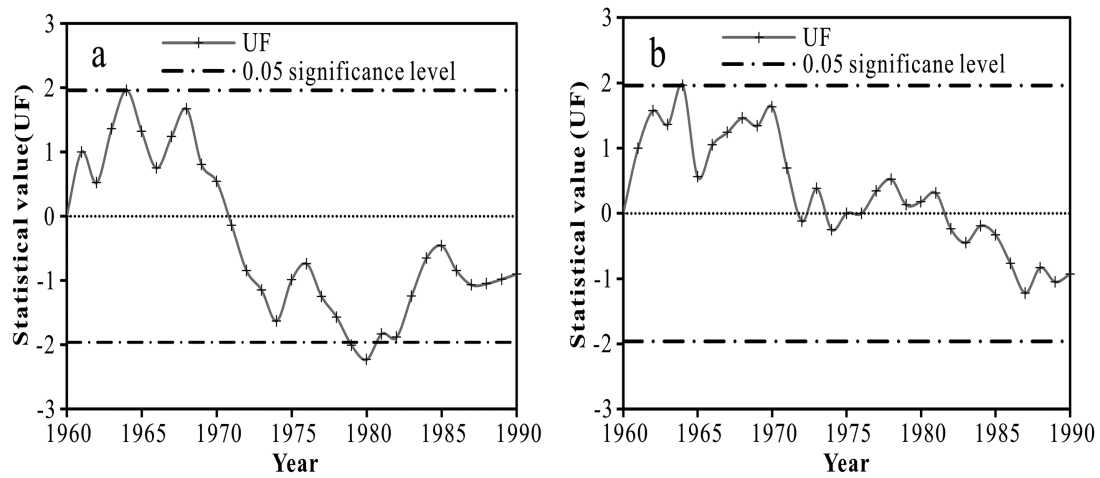

Figure 5. Mann-Kendall test for annual water discharge (a) and suspended sediment load (b); UF is the statistical value. 

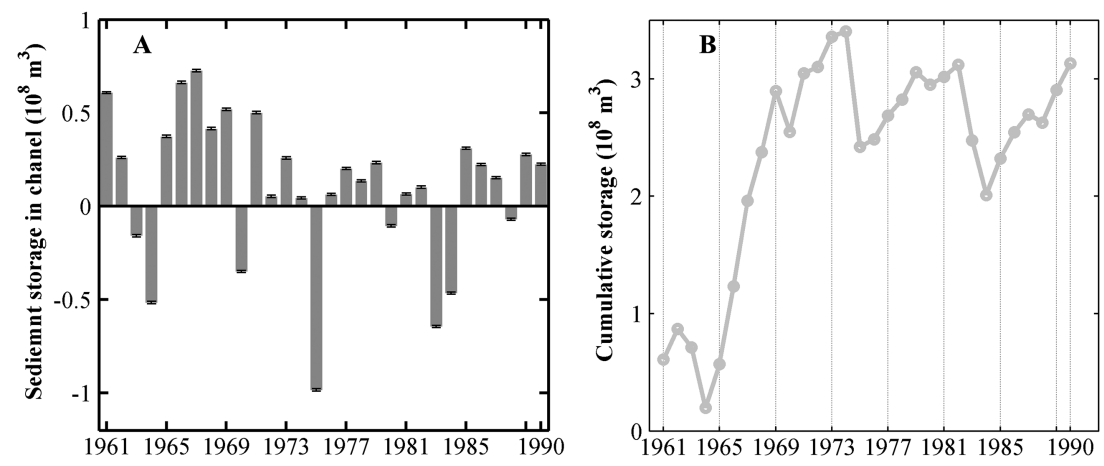

Figure 6. (A) Annual sediment storage in the channel and its uncertainty during the period 1960-1990 (positive value represents deposition); (B) cumulative sediment storage in the channel during the period 1960-1990.
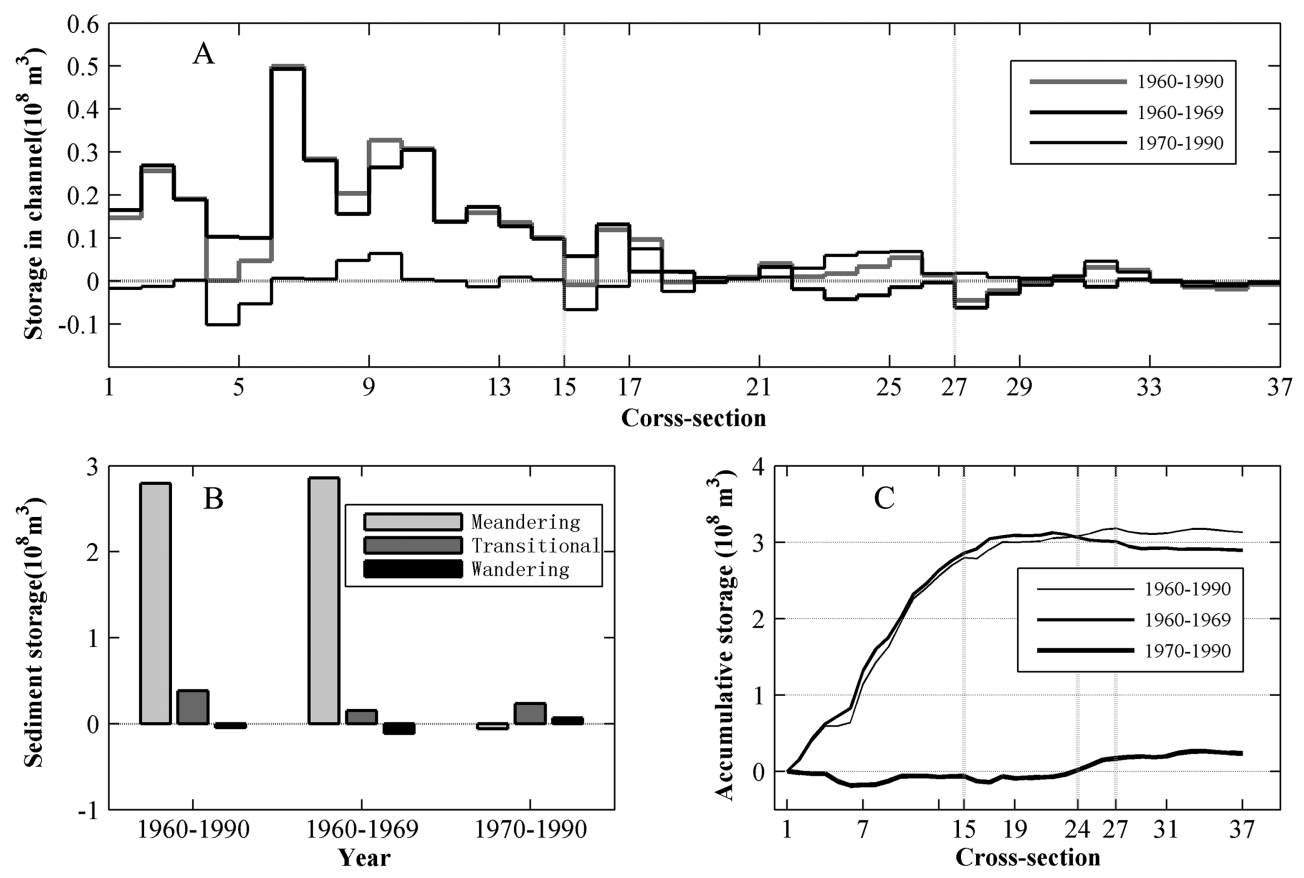

Figure 7. (A) Spatial variations of the sediment storage between adjacent cross-sections in the periods 1960-1990, 1960-1969, and 1970-1990; (B) sediment storage in three river reaches with different channel patterns in each period (positive values represent deposition); (C) cumulative sediment storage in the channel upstream of CS1 showing the accumulation rate in each period. This figure is available in colour online at wileyonlinelibrary.com/journal/espl

Results showed a significant spatial variation with a general upstream decreasing tendency.

In the period 1960-1969, deposition dominated the meandering reach $(\mathrm{CS} 1-15)$ at a mean rate of $0.32 \times 10^{8} \mathrm{~m}^{3} \mathrm{yr}^{-1}$ (Figure $7(\mathrm{~B}),(\mathrm{C}))$. In contrast, the deposition rate of $0.02 \times 10^{8} \mathrm{~m}^{3} \mathrm{yr}^{-1}$ was much lower in the transitional reach (CS15-27). Scouring and filling occurred alternately in the wandering reach $(\mathrm{CS} 27-\mathrm{CS} 37)$ at an erosion rate of $0.01 \times 10^{8} \mathrm{~m}^{3} \mathrm{yr}^{-1}$, and thus this reach acted as a small sediment source.

Deposition and erosion patterns were significantly altered in 1970-1990. The meandering reach changed from a large sediment sink into a sediment source (Figure $7(\mathrm{C})$ ), as indicated by an erosion rate of $-0.003 \times 10^{8} \mathrm{~m}^{3} \mathrm{yr}^{-1}$. The wandering reach became a sediment sink with a volume of $0.003 \times 10^{8} \mathrm{~m}^{3} \mathrm{yr}^{-1}$. Only the transitional reach remained as a sediment sink with an aggradation rate $\left(0.014 \times 10^{8} \mathrm{~m}^{3} \mathrm{yr}^{-1}\right)$ that was nearly the same as in the former period.

In summary, in the period 1960-1990, the meandering reach acted as a sediment sink that suffered heavy aggradation with a mean value of $0.093 \times 10^{8} \mathrm{~m}^{3} \mathrm{yr}^{-1}$. Compared with the meandering reach, the transitional reach acted as a relatively smaller sink $\left(0.017 \times 10^{8} \mathrm{~m}^{3} \mathrm{yr}^{-1}\right)$, and the wandering reach behaved as a sediment source with an erosion rate of $0.013 \times 10^{8} \mathrm{~m}^{3} \mathrm{yr}^{-1}$.

\section{Sediment storage on the floodplain}

Compared with the channel, the floodplain was much more important as a sediment sink, indicated by a total storage of $5.74 \pm 0.05 \times 10^{8} \mathrm{~m}^{3}$, which was 1.8 times that in the channel.

Temporal variations of aggradation

The annual sediment storage on the floodplain was also considerably variable with time (Figure $8(\mathrm{~A})$ ). The first period of 1960-1969 featured a large accumulation rate of $0.51 \times 10^{8} \mathrm{~m}^{3} \mathrm{yr}^{-1}$ with a total volume of $4.6 \pm 0.03 \times 10^{8} \mathrm{~m}^{3}$, which accounted for $80 \%$ of the total in the two periods (Figure $8(\mathrm{~B})$ ). Moreover, most sediment was trapped in the period 1966-1968 with a total of $3.97 \pm 0.02 \times 10^{8} \mathrm{~m}^{3}$. Sediment storage was approximately $1.14 \pm 0.04 \times 10^{8} \mathrm{~m}^{3}$ in the period 1970-1990 with a rate of $0.05 \times 10^{8} \mathrm{~m}^{3} \mathrm{yr}^{-1}$. Furthermore, in the years from 1969 to 1982, the sediment storage was $1.53 \pm 0.04 \times 10^{8} \mathrm{~m}^{3}$. The stepped cumulative curve in this period resembled an integer function with jumps in 1970, 

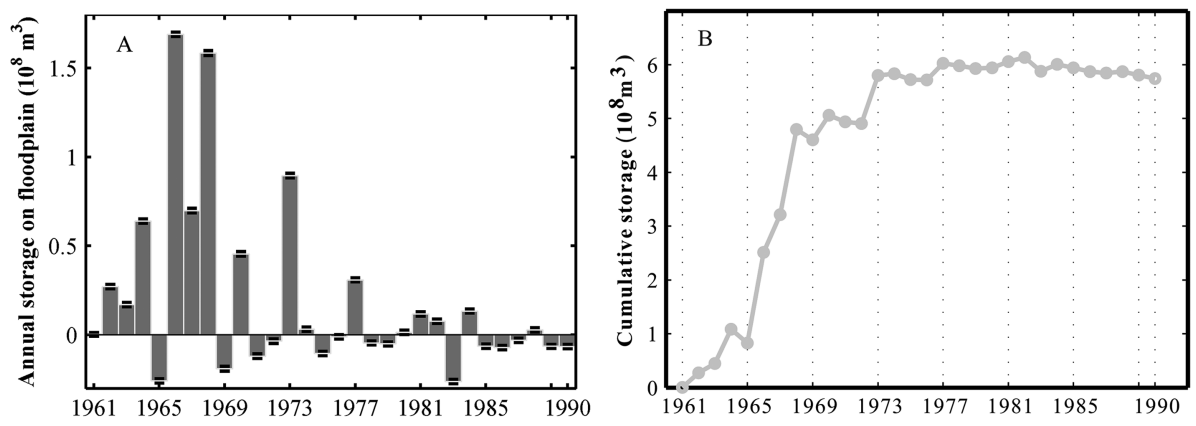

Figure 8. (A) Annual sediment storage on the floodplain (the uncertainty of the sediment storage in each year is represented by error bars); (B) the cumulative annual storage on the floodplain (negative values represent erosion).

1973, and 1977. Considering the entire series of annual aggradation, the floodplain acted as a large sediment sink in the period 1960-1983. In contrast, this area became a sediment source with a total erosion of $0.4 \times 10^{8} \mathrm{~m}^{3}$ due to the bank erosion in the period 1983-1990.

Spatial variations of sediment storage on the floodplain The sediment storage was found to be highly variable spatially (Figure 9(A)). Generally, sediment storage on the floodplain decreased with the distance from CS1, and aggradation dominated nearly all the reaches with several exceptions.

The pattern of sediment storage on the floodplain was similar to that in the channel. Aggradation on the floodplain dominated the meandering reach in 1960-1969, accounting for approximately $75 \%$ of the total storage on the floodplain (Figure 9(B), (C)). The deposition rate in the transitional reach ranked the second highest with values of $0.027 \times 10^{8} \mathrm{~m}^{3} \mathrm{yr}^{-1}$ and $0.021 \times 10^{8} \mathrm{~m}^{3} \mathrm{yr}^{-1}$ in 1960-1969 and 1970-1990, respectively. In contrast, the sedimentation in the wandering reach was much smaller with a value between 0.001 and $0.002 \times 10^{8} \mathrm{~m}^{3} \mathrm{yr}^{-1}$ in the periods 1960-1969 and 1970-1990.

\section{Sediment output}

In this paper, we chose CS1 as the catchment outlet, and the annual sediment output and error propagation were estimated (Figure 10). The results showed that sediment output was variable between years. Although the sediment output displayed a declining trend, the SDR increased from $75 \%$ in $1960-1969$ to $97 \%$ in $1970-1990$.

\section{Sediment budget}

Based on the data described above, the sediment budgets were established as presented in Table II and illustrated in Figure 11.

In the period $1960-1990, \sim 11 \%$ of the sediment moving into the lower Wei River was trapped. Approximately $65 \%$ of the total sediment storage was stored on the floodplain, whereas 35\% was stored in the channel. The meandering reach (CS1-CS15) experienced the most severe change in sediment storage, accounting for $79 \%$ of the total storage.

Comparing the sediment budgets for the two periods 1960-1969 and 1970-1990 (Figure 11(B), (C)), one distinct difference between them is that the deposition rate was 13 times
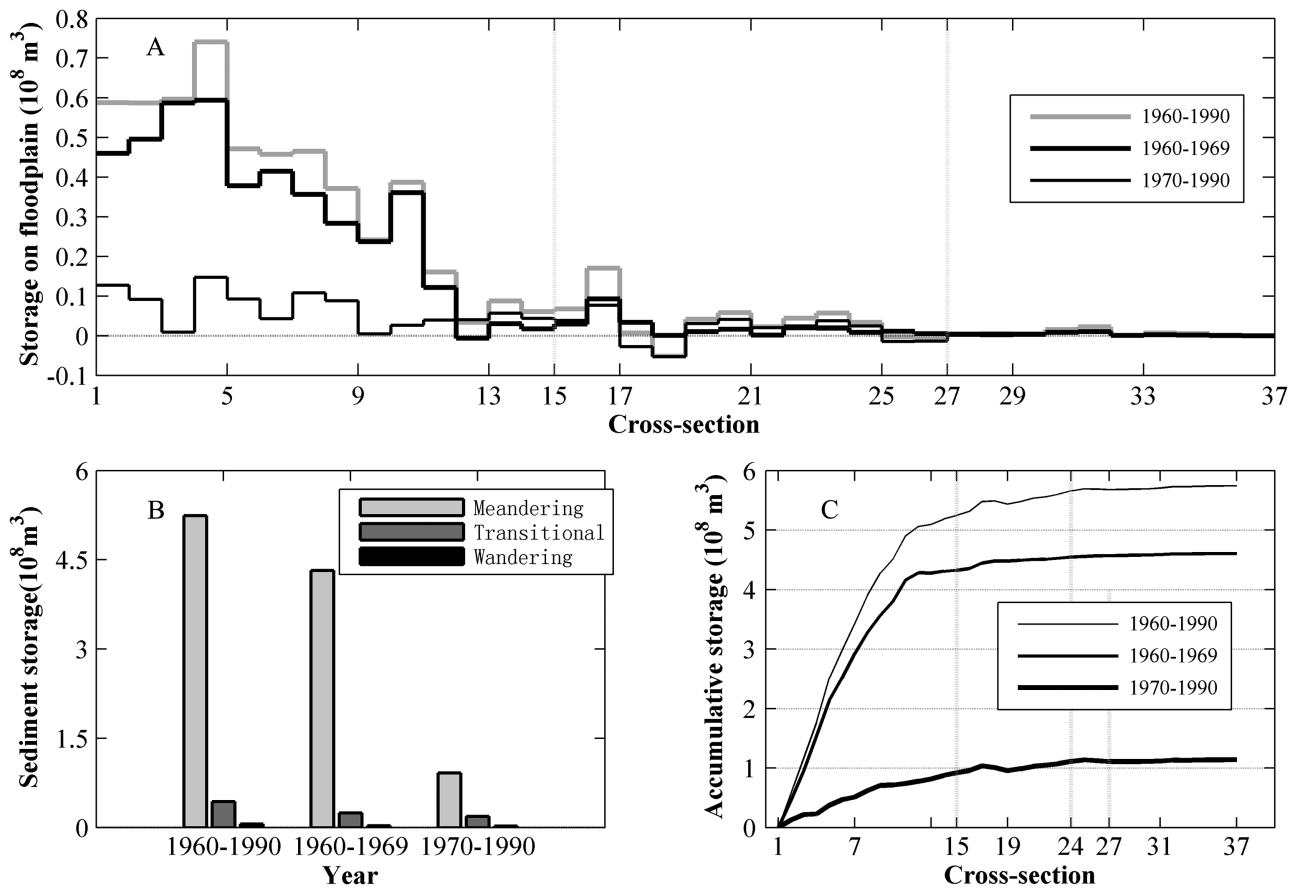

Figure 9. (A) Spatial variation of sediment storage between adjacent cross-sections on the floodplain in the periods of 1960-1990, 1960-1969, and 1970-1990 (negative values represent erosion); (B) sediment storage in reaches with different channel patterns during each period; (C) cumulative sediment storage on the floodplain upstream CS1 illustrating the accumulation rates in each period. 


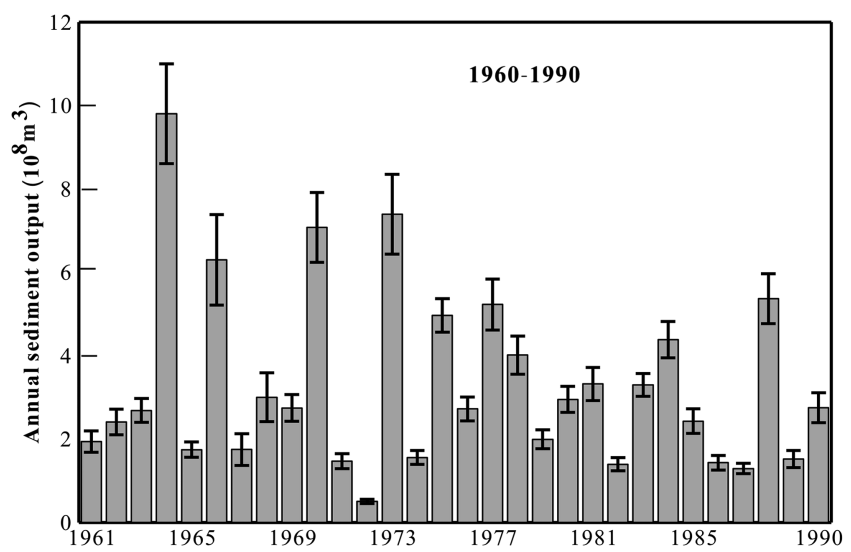

Figure 10. Annual sediment output at CS1 in the lower Wei River (uncertainties are presented as error bars).

Table II. Sediment budgets for the lower Wei River in the periods 1960-1990, 1960-1969, 1970-1990 (10 tyr-1)1960-1990, 1960-1969, 1970-1990 (10 ${ }^{8}$ tyr-1)

\begin{tabular}{lccc}
\hline $\begin{array}{l}\text { Sediment budget } \\
\text { component }\end{array}$ & $1960-1969$ & $1970-1969$ & $1960-1990$ \\
\hline $\begin{array}{l}\text { Sediment input } \\
\text { Upper stream }\end{array}$ & & & \\
Jing river & 2.003 & 1.123 & 1.387 \\
Sediment storage & & 2.159 & 2.338 \\
Channel & & & \\
$\quad$ Meandering reach & 0.444 & -0.004 & 0.130 \\
$\quad$ Transitional reach & 0.024 & 0.015 & 0.018 \\
Wandering reach & -0.018 & 0.004 & -0.002 \\
$\quad$ Total in channel & 0.451 & 0.016 & 0.146 \\
$\quad$ Floodplain & & & \\
$\quad$ Meandering reach & 0.673 & 0.061 & 0.245 \\
$\quad$ Transitional reach & 0.038 & 0.013 & 0.020 \\
Wandering reach & 0.005 & 0.002 & 0.003 \\
$\quad$ Total on floodplain & 0.716 & 0.076 & 0.268 \\
Sediment output (SDR) & 3.594 & 3.19 & 3.311 \\
$\quad(77.73 \%)$ & $(97.21 \%)$ & $(88.29 \%)$ \\
\hline
\end{tabular}

higher in the period 1960-1969. Moreover, the channel in the meandering reach was transformed from a sediment sink in the period 1960-1969 to a minor sediment source in the period 1970-1990.

\section{Discussion}

\section{Errors in sediment budgets}

The errors in the sediment budgets could originate from several uncertainties. First, using the Monte Carlo method, the uncertainty of the annual suspended sediment load was found to be approximately $10.8 \%$. Second, the uncertainty of sediment storage in the channel was estimated as approximately $0.034 \times 10^{8} \mathrm{~m}^{3}$ with a relative uncertainty of $\sim 1.1 \%$, and the uncertainty of the sediment storage on the floodplain was approximately $0.068 \times 10^{8} \mathrm{~m}^{3}(1.2 \%)$ according to the method given in Reid et al. (2007). Third, the soil organic matter content is not addressed in the study. Nevertheless, the organic matter content in deposits on the floodplain is less than $1 \%$ (Dang, 2012), and thus, the total sediment storage will only be reduced by $1 \%$ if the organic matter content is taken into consideration. Fourth, the spatial and temporal variation of the sediment bulk density will significantly affect the sediment budget when the volume of sediment storage is transformed into a mass. No detailed data are available for the bulk density, and thus, a mean value of $1.4 \mathrm{~g} \mathrm{~cm}^{-3}$ is adopted, which is similar to the findings of Cheng et al. (1993). Assuming a bulk density between $1.35 \mathrm{~g} \mathrm{~cm}^{-3}$ and $1.45 \mathrm{~g} \mathrm{~cm}^{-3}$, the sediment storage will fluctuate over a range of $\pm 3.6 \%$. Fifth, the sediment load in other smaller tributaries is not considered in constructing the sediment budgets. These tributaries are separated into those flowing down the north slope of the Qinling Ranges on the south side of the lower Wei River and those flowing down the Loess Plateau on the north side. These tributaries have a total drainage area of approximately $15723 \mathrm{~km}^{2}$, and only a portion of the tributaries have records for sediment load. The mean sediment yield of the gauged tributaries on each side of the lower Wei River is calculated. Assuming that either of the mean sediment yields represents those of the un-gauged tributaries on the same side of the study reach, the annual total amount of sediment produced from all of the small tributaries is found as approximately $0.146 \times 10^{8} \mathrm{tyr}^{-1}$, which is less than $4 \%$ of the sediment input given in Figure 11(A) during the period 1960-1990. Therefore, excluding the sediment yield of small tributaries from the sediment input results in only negligible error.

Although the errors in sediment budgets may be due to many causes and are not easy to define accurately, these errors are not sufficiently large to produce a biased view of the sediment flux in the studied river, as evidenced by comparing the measured sediment output at the Huayin gauging station with the calculated sediment output. Figure 12 shows that good agreement between the measured sediment yield $\left(3.44 \times 10^{8} \mathrm{t}\right)$ and the calculated sediment yield $\left(3.35 \times 10^{8} \mathrm{t}\right)$ in the periods during which the sediment load was gauged at the Huayin station, thus demonstrating the accuracy of the above sediment budget to a certain extent. In performing the comparison, the sediment load recorded only during flood seasons in the years from 1976 to 1990 at the Huayin station is assumed as the annual total because the sediment load in the flood seasons is more than $90 \%$ of the annual total.

\section{Sediment delivery and controls}

\section{Sediment input}

Compared with the period 1960-1969 without SWC measures, the SSL values of the Jing River and upstream mainstream were reduced by $21.7 \%$ and $43.9 \%$ in the period $1970-1990$, respectively (Figure 11). The reduction of SSL, which is also demonstrated by the Mann-Kendall test (Figure 5), might be controlled by SWC practices and climate change.

The SWC measures are widely demonstrated as effective sediment control strategies (Trimble, 1999; Walling and Fang, 2003). For the lower Wei River, Ran (2006) estimated that the soil erosion was reduced by $0.216 \times 10^{8} \mathrm{tyr}^{-1}, 0.156 \times 10^{8} \mathrm{tyr}^{-1}$, $0.033 \times 10^{8} \mathrm{tyr}^{-1}$, and $0.138 \times 10^{8} \mathrm{tyr}^{-1}$ after the implementation of terraces, woodlands, grasslands, and check dams, respectively, in the period 1970-1989. It was suggested that the coupling between the channel and hillslope was highly reduced after the implementation of SWC measures, resulting in lower soil erosion and higher storage on the hillslope. Moreover, the decline of the sediment input indicated that the degree of decoupling tended to increase with time as the SWC measures gradually exerted their influences (Figure 5), which was also demonstrated by Wang et al. (1994). They found that the SWC practices accounted for $53 \%$ of the reduction of sediment yield in the 1970s and a higher level of $87 \%$ in the 1980s. 


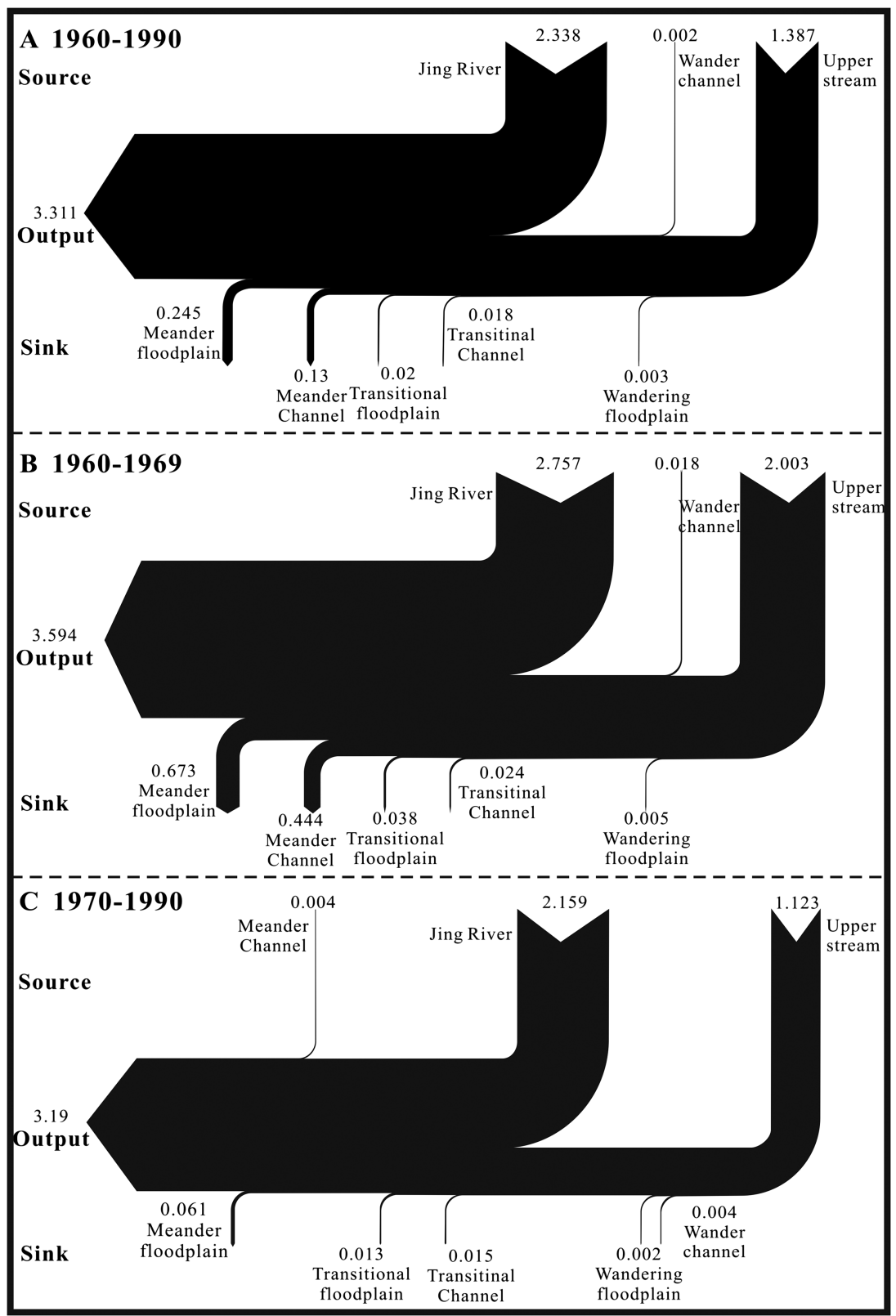

Figure 11. Sediment budgets for the lower Wei River in the periods 1960-1990 (A), 1960-1969 (B), and 1970-1990 (C). Each component is expressed in $108 \mathrm{tyr}^{-1}$. 'Wandering', 'Transitional', and 'Meandering' represent the channel and floodplain sections of the wandering reaches (CS37-CS27), transitional reaches (CS15-CS27), and meandering reaches (CS15-CS1), respectively.

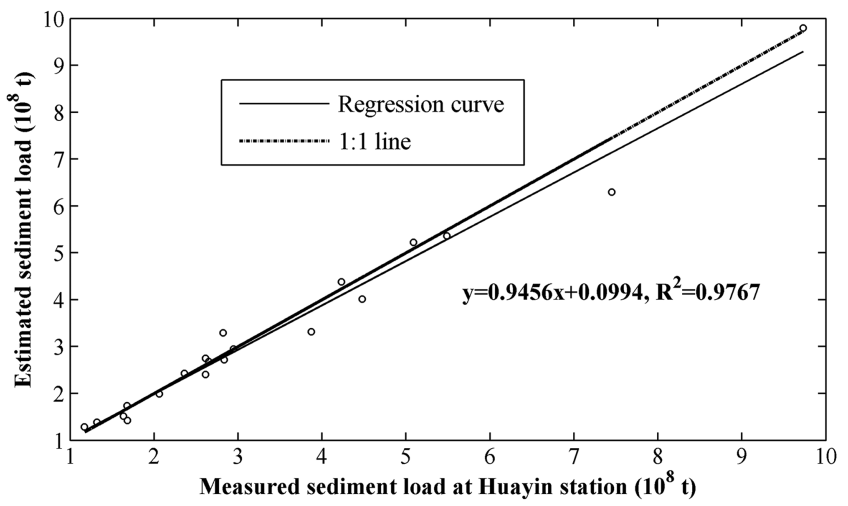

Figure 12. Relationship between the measured sediment flux at the Huayin station and the estimated sediment output based on Equation (1).

Inversely, climate conditions are one of the factors that trigger soil erosion, particularly precipitation. Consequently, the decline in precipitation in the lower Wei River might also contribute to the decoupling between hillslopes and channels and thus the reduction of sediment load in the period 1970-1990. Based on the intensity and duration of precipitation events, Wang et al. (1994) suggested that the contributions of climate change to the decrease in sediment load were $47 \%$ and $21.3 \%$ in the periods $1970-1979$ and 1980-1989, respectively. Both the SWC measures and the decline of precipitation resulted in the decrease in sediment input.

Sediment storage in the channel and on the floodplain With respect to the catchment sediment delivery, sediment storage is always considered as the key process for explaining the discrepancy between the sediment input and the sediment yield (Lecce et al., 2006; Slattery and Phillips, 2011; Fryirs, 2013). Controls that affect the sediment storage include vegetation (Darke and Megonigal, 2003; Lecce et al., 2006), water and sediment regime (Gautier et al., 2010), base level (Shi, 2005), and human activities (Trimble, 1999; Syvitski et al., 2005) among others. In the lower Wei River, factors that affect the sediment storage may be ascribed to two 
controls: (1) the Tongguan elevation (base level), which is primarily affected by the operation modes of Sanmenxia Dam (Wu et al., 2004); and (2) the temporal variation of sedimentwater regime due to SWC practices and climate change.

A prominent temporal variation was found in the sediment storage in the channel and on the floodplain of the lower Wei River in the current study (Figures 6 and 8). Linear regression was used to explore the relationships among sediment storage, water-sediment regime, and base level. Compared with the incoming water-sediment regime (Figures 13, 14(A1), (B1), (C1)), the dominant cause for the severe sediment storage in the channel and on the floodplain could be the Tongguan elevation in the period 1960-1969, indicated by a much higher $\mathrm{R}^{2}$ of the relationship between the accumulative sediment storage and the Tongguan elevation, which was also demonstrated by Wang et al. (2004). The operational modes in this period were 'storage' and 'flood detention'. Consequently, the Tongguan elevation increased rapidly from $323.66 \mathrm{~m}$ in 1960 to $328.65 \mathrm{~m}$ in 1969 at a rate of $0.55 \mathrm{~m} \mathrm{yr}^{-1}$ (Figure 13); it is clear that significant aggradation $\left(0.451 \times 10^{8} \mathrm{tyr}^{-1}\right)$ occurred because of the reduction of sediment mobility caused by low stream power (Walter and Merritts, 2008; Frings et al., 2014). During the period from November 1970 to 1990, the processes of bank erosion and channel down-cutting began to play a much more important role in certain years; the sediment storage was evidently smaller than before (Figure 6(B), 8(B), 11(C)), and the pool level of the dam was much lower than before. As a result, the Tongguan elevation declined and fluctuated in a much smaller range of approximately $327.47 \pm 0.49 \mathrm{~m}$. Only $0.015 \times 10^{8} \mathrm{tyr}^{-1}$ and $0.076 \times 10^{8} \mathrm{tyr}^{-1}$ of sediment were sequestered in the channel and on the floodplain, respectively (Figure $11(\mathrm{C})$ ). In this period, the impact of the Tongguan elevation declined compared with that of the period 1960-1969, but the deposition in the channel showed a weak positive relationship with the base level $\left(P=0.047, \mathrm{R}^{2}=0.19\right)$ (Figure 14(A2)). In contrast, a higher $\mathrm{R}^{2}$ of 0.54 was found between the discharge in wet seasons and the annual storage in the channel (Figure 14(B2)). A better relationship was found between the SSL in wet seasons and the annual storage on the floodplain, indicated by an $\mathrm{R}^{2}$ of 0.61 , but an insignificant relationship was found between the base level and the annual storage on the floodplain (Figure 14(A2), (C2)).

The spatial variation of the sediment storage might be predominantly caused by the headward accumulation or erosion (Wang et al., 2004, 2005). Figure 11(B) illustrates a longitudinal pattern of sedimentation characterized by a downstream increasing trend. During the period 1960-1969, the headward accumulation was severe because of the rapid increase of the Tongguan elevation. As a result, the deposition rate was approximately $0.67 \times 10^{8} \mathrm{tyr}^{-1}$ in the meandering reach (Figure 11(B)). However, in the period 1970-1990, the Tongguan elevation was reduced to a mean value of $327.02 \mathrm{~m}$, the headward accumulation was therefore significantly reduced, and in the meandering reach, it was even replaced by headward erosion (Figure 11(C)).

Sediment discharge at the outlets

Similar to many other rivers in the world (Table III, Walling and Fang, 2003), sediment output from the Wei River showed a decreasing trend (Figure 11(B), (C)). In addition, human modifications became the primary control for the decline in the sediment output of the lower Wei River, as in other rivers in the world (Table III). Before 1960, the lower Wei River was nearly at grade, and thus, sediment was transported through this river with an SDR close to one (GSWR, 1983). During the period 1960-1969, the sediment input was $4.76 \times 10^{8} \mathrm{tyr}^{-1}$, whereas the sediment output was $3.594 \times 10^{8}$ tyr $^{-1}$ after the impoundment of Sanmenxia Dam in 1960. It was obvious that the sharp increase in the Tongguan elevation, which acted as a barrier (Walling and Fang, 2003; Syvitski et al., 2005), reduced the sediment output by detaining sediment, leading to a decline of 0.22 in the SDR. In 1970-1990, the sediment output was further reduced by $11.2 \%\left(3.19 \times 10^{8} \mathrm{tyr}^{-1}\right)$, whereas the sediment input was reduced by $31.1 \%\left(3.28 \times 10^{8} \mathrm{tyr}^{-1}\right)$. The higher SDR of 0.97 indicated that the function of sediment detainment by the raised base level had been weakened. Although the SDR was high in this period, the sediment output was lower than that in the previous period, illustrating that a significant reduction of sediment input was the principal cause for the decline of sediment output.

\section{Connectivity in the fluvial sediment cascades}

The sediment connectivity represents the sediment delivery efficiency and reflects the processes that drive the changes in sediment conveyance in a river basin to a certain degree (Hooke, 2003; Fryirs, 2013). In this work, based on the established sediment budgets, the connectivity of the upstream-downstream, tributary-trunk, and floodplain-channel are briefly discussed to

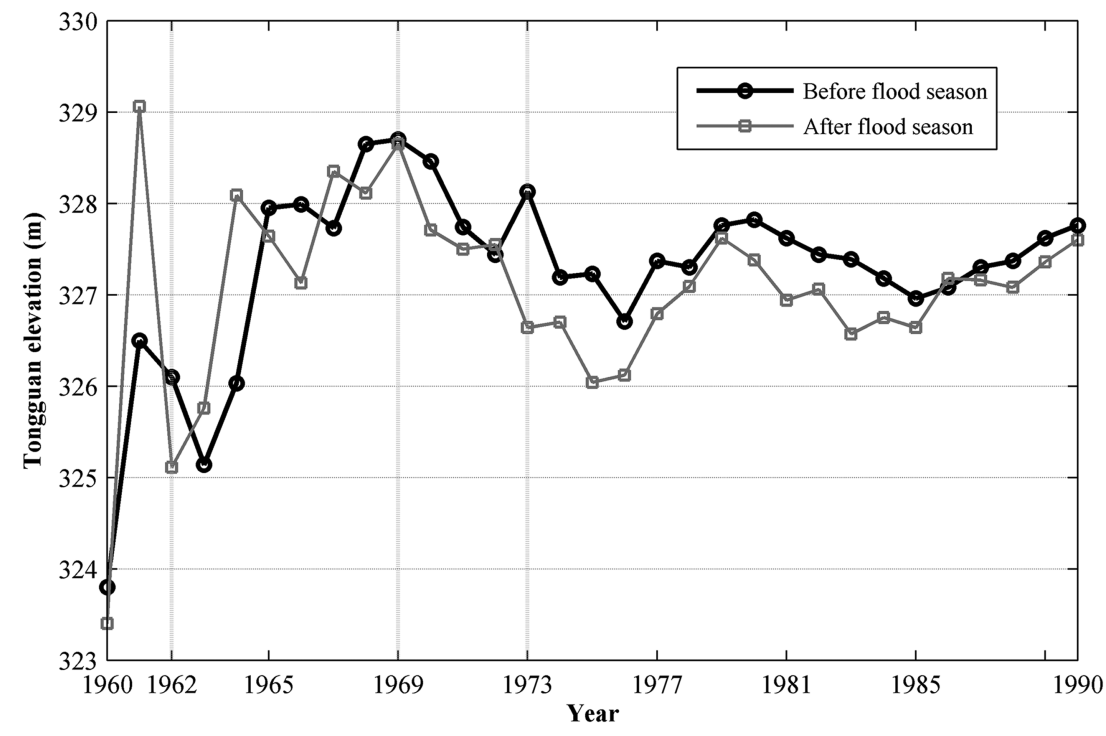

Figure 13. Changes in the Tongguan elevation at the ends of the dry seasons (May) and wet seasons (October) in the period 1960-1990. 


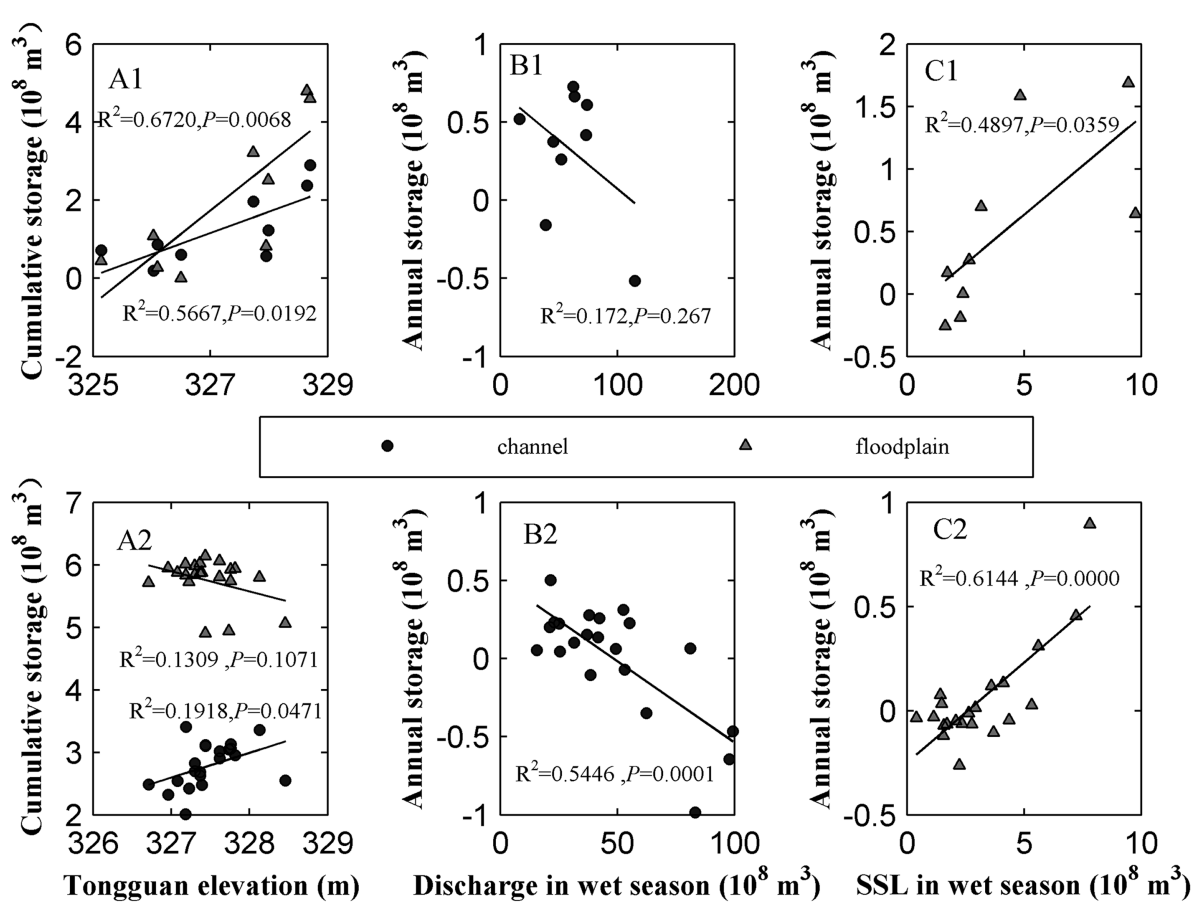

Figure 14. Correlations of the Tongguan elevation vs. cumulative storage in the channel (dot) and on the floodplain (triangle) (A1, A2); water discharge in the wet seasons vs. the annual storage in the channel (B1, B2); and SSL in the wet seasons vs. the annual storage on the floodplain $(\mathrm{C} 1, \mathrm{C} 2)$ in two periods.

Table III. Changes of sediment flux of some major rivers worldwide

\begin{tabular}{|c|c|c|c|c|}
\hline Basin & Area $\left(\mathrm{km}^{2}\right)$ & Sediment discharge & Causes & Author \\
\hline Yellow River & $75 \times 10^{4}$ & $1080 \mathrm{Mt} \mathrm{yr}^{-1}$ in $1950-1964,150 \mathrm{Mt} \mathrm{yr}^{-1}$ in $2000-2005$ & Dams, SWC measures & Wang et al., 2007 \\
\hline Yangtze River & $181 \times 10^{4}$ & $472 \mathrm{Mt} \mathrm{yr}^{-1}$ in $1950-1980,124 \mathrm{Mt} \mathrm{yr}^{-1}$ after 1993 & Three Gorge Dam & Chen et al., 2008 \\
\hline Missippissi & $322 \times 10^{4}$ & $400 \mathrm{Mt} \mathrm{yr}^{-1}$ before $1900,145 \mathrm{Mt} \mathrm{yr}^{-1}$ in 1987-2006 & $\begin{array}{l}\text { Dam construction, engineering } \\
\text { structures }\end{array}$ & Meade and Moody, 2010 \\
\hline Colorado & $63 \times 10^{4}$ & $125 \mathrm{Mt} \mathrm{yr}^{-1}$ before $1930,0.1 \mathrm{Mt} \mathrm{yr}^{-1}$ after 1930 & Dam construction & Meade and Parker, 1985 \\
\hline Nile & $280 \times 10^{4}$ & $160 \mathrm{Mt} \mathrm{yr}^{-1}$ in 1960-1964, nearly $0 \mathrm{Mt} \mathrm{yr}^{-1}$ after 1964 & Aswan Dam & Fanos, 1995 \\
\hline
\end{tabular}

highlight the causes for changes in sediment delivery through the study reaches.

According to the sediment budget, the longitudinal upstreamdownstream connectivity was enhanced because the SDR increased from $75 \%$ in $1960-1969$ to $97 \%$ in 1970-1990 (Figure 11(B), (C)). The variation of connectivity was related to the change in the Tonggugan elevation. In the period 1960-1969, the rise of the Tongguan elevation induced by the closure of the Sanmenxia Dam resulted in a relatively lower connectivity. During the period 1970-1990 while the Tongguan elevation declined, the connectivity was increased.

The lateral sediment connectivity between the channel and floodplain shows a bidirectional character. Mainly driven by overbank inundation, sediment is delivered from the channel to the floodplain, leading to the increase of floodplain sediment storage. On the other hand, sediment can be transferred from the floodplain to the channel by certain processes, among which the important one is bank erosion, which reduces the floodplain sediment storage. In this work, we define the direction of delivery of sediment from the channel to the floodplain as positive and the opposite direction as negative. In the period 1960-1969, the positive lateral connectivity between the channel and floodplain was enhanced because the frequency of overbank events was increased by the rise of the Tongguan elevation. The positive connectivity caused significant sediment deposition at an intensity of $0.72 \times 10^{8} \mathrm{tyr}^{-1}$ on the floodplain (Figure 11(B)). In the period 1970-1990, the positive lateral connectivity was reduced as the Tongguan
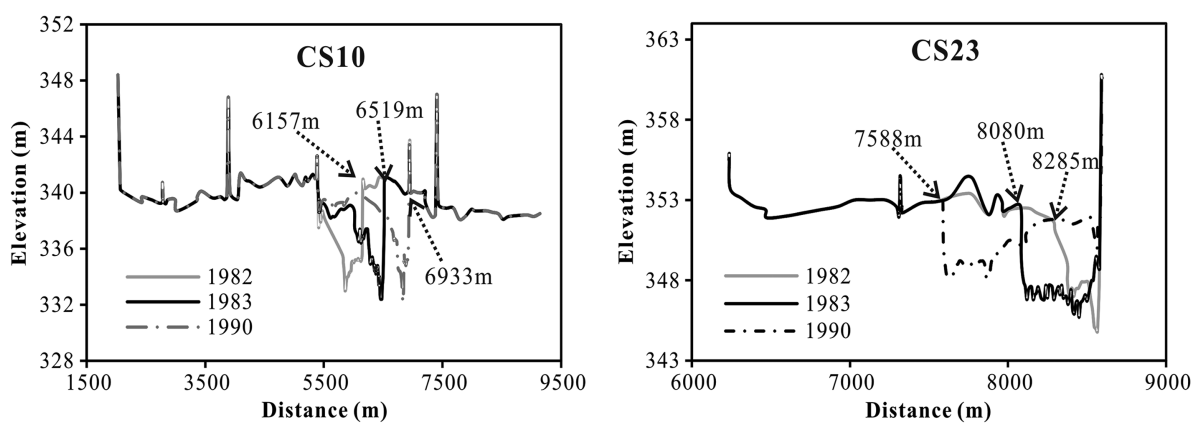

Figure 15. Changes in cross-sections CS10 and CS23 illustrating the bank erosion in the lower Wei River. 
elevation declined, and the deposition rate on the floodplain was only $0.08 \times 10^{8} \mathrm{tyr}^{-1}$ (Figure $11(\mathrm{C})$ ). Moreover, the negative connectivity was enhanced, resulting in a further reduction of the sedimentation rate on the floodplain. The intensification of negative lateral connectivity could be attributed to bank erosion. Figure 15 shows the bank erosion at two cross-sections. At CS10, the right bank retreated by $776 \mathrm{~m}$ in the period from 1982 to 1990 at a mean rate of $97 \mathrm{~m} \mathrm{yr}^{-1}$. The rate of bank erosion was $87 \mathrm{~m} \mathrm{yr}^{-1}$ at CS23 in the same period.

The connectivity between the tributaries and trunk was reduced, as shown by the reduction of sediment input from $4.76 \times 10^{8} \mathrm{t}$ in $1960-1969$ to $3.28 \times 10^{8} \mathrm{t}$ in $1970-1990$. The reduction was associated with SWC practices and climate change, in which the SWC practices acted as a sediment barrier that impeded the conveyance of sediment from the hillslope to the channel.

\section{Conclusion}

This study investigated the changes in the sediment delivery and connectivity properties of the lower Wei River induced by modifications of the catchment and base level controls. The sediment budgets indicated that the mean sediment input was significantly reduced from $4.76 \times 10^{8} \mathrm{tyr}^{-1}$ in 1960-1969 to $3.28 \times 10^{8}$ tyr $^{-1}$ in $1970-1990$ due to both SWC practices and climate change.

The spatial and temporal variations of deposition and erosion in the channel and on the floodplain were primarily affected by the Tongguan elevation as well as SWC practices and climate change. The Tongguan elevation was increased conspicuously in the period 1960-1969 during which the operational modes were 'storage' and 'flood detention', leading to a high positive lateral connectivity between the channel and floodplain and in turn to large sediment storage values of $0.451 \times 10^{8} \mathrm{tyr}^{-1}$ in the channel and $0.716 \times 10^{8} \mathrm{tyr}^{-1}$ on the floodplain. Furthermore, deposition occurred primarily in the meandering reach because of headward accumulation. In contrast, in the period 1970-1990, because of the favorable water-sediment regime and a slight decline in the Tongguan elevation, the negative lateral connectivity between the channel and floodplain was enhanced. Sediment was trapped at the much lower rates of $0.016 \times 10^{8} \mathrm{tyr}^{-1}$ and $0.076 \times 10^{8} \mathrm{tyr}^{-1}$ in the channel and on the floodplain, respectively. Sediment was released into the channel through bank erosion and down-cutting. The declines in both sediment output and SDR in the period 1960-1969 were caused by dam trapping. The sediment output remained at a lower level primarily due to SWC practices and climate change, but the SDR was higher as a result of the enhanced longitudinal connectivity between upstream and downstream in 1970-1990.

Acknowledgements - This study was funded by the National Natural Science Foundation of China (Grant No. 41371036, 40971012) and the National Major Basic Research Program of China (Grant No. 2011CB403305). We thank the Yellow River Conservancy Commission of the Ministry of Water Resources for providing the water, sediment, and cross-section data. We also appreciate the helpful comments from the editors and two anonymous reviewers.

\section{References}

Beven K, Heathwaite L, Haygarth P, Walling D, Brazier R, Withers P. 2005. On the concept of delivery of sediment and nutrients to stream channels. Hydrological Processes 19(2): 551-556.

Chen X, Yan Y, Fu R, Dou X, Zhang E. 2008. Sediment transport from the Yangtze River, China, into the sea over the Post-Three Gorge Dam Period: a discussion. Quaternary International 186(1): 55-64.
Cheng LY, Xi ZP, Liu YE. 1993. Research and application of sediment dry bulk density in Sanmenxia Dam. Yellow River 11: 8-10.

Dang N. 2012. The prediction of heavy metals and organic matters used of reflectance spectroscopy in the sediment of Shanxi section of Weihe River. Thesis, Shanxi University of Science and Technology.

Darke A, Megonigal JP. 2003. Control of sediment deposition rates in two mid-Atlantic Coast tidal freshwater wetlands. Estuarine, Coastal and Shelf Science 57(1): 255-268.

Delmas M, Pak L-T, Cerdan O, Souchère V, Le Bissonnais Y, Couturier A, Sorel L. 2012. Erosion and sediment budget across scale: a case study in a catchment of the European loess belt. Journal of Hydrology 420: $255-263$.

Evans M, Warburton J. 2005. Sediment budget for an eroding peatmoorland catchment in northern England. Earth Surface Processes and Landforms 30(5): 557-577.

Fanos AM. 1995. The Impact of human activities on the erosion and accretion of the Nile delta coast. Journal of Coastal Research 11(3): 821-833.

Florsheim JL, Mount JF, Rutten LT. 2001. Effect of baselevel change on floodplain and fan sediment storage and ephemeral tributary channel morphology, Navarro River, California. Earth Surface Processes and Landforms 26(2): 219-232.

Frings RM, Gehres N, Promny M, Middelkoop $H$, Schüttrumpf $H$, Vollmer S. 2014. Today's sediment budget of the Rhine river channel, focusing on the Upper Rhine Graben and Rhenish Massif. Geomorphology 204: 573-587.

Fryirs K. 2013. Connectivity in catchment sediment cascades: a fresh look at the sediment delivery problem. Earth Surface Processes and Landforms 38: 30-46.

Fryirs KA, Brierley GJ, Preston NJ, Kasai M. 2007. Buffers, barriers and blankets: the connectivity of catchment-scale sediment cascades. Catena 70(1): 49-67.

Gautier E, Brunstein D, Vauchel P, Jouanneau JM, Roulet M, Garcia C, Guyot J, Castro M. 2010. Channel and floodplain sediment dynamics in a reach of the tropical meandering Rio Beni (Bolivian Amazonia). Earth Surface Processes and Landforms 35(15): 1838-1853.

GSWR (Group of Study on Wei River, Institute of Geography, Chinese Academy of Sciences). 1983. Fluvial Geomorphology of the Lower Wei River. Science Press: Beijing.

Heckmann T, Schwanghart W. 2013. Geomorphic coupling and sediment connectivity in an alpine catchment - exploring sediment cascades using graph theory. Geomorphology 182: 89-103.

Higgitt D, Lu X. 2001. Sediment delivery to the three gorges: 1 . Catchment controls. Geomorphology 41(2): 143-156.

Holliday VJ, Warburton J, Higgitt DL. 2008. Historic and contemporary sediment transfer in an upland Pennine catchment, UK. Earth Surface Processes and Landforms 33(14): 2139-2155.

Hooke J. 2003. Coarse sediment connectivity in river channel systems: a conceptual framework and methodology. Geomorphology 56: 79-94.

Jain V, Tandon S. 2010. Conceptual assessment of connectivity and its application to the Ganga river dispersal system. Geomorphology 118(3): 349-358.

Jiao JY, Ma XY, Wang F, Wang WZ. 2004. Regional variation features of sediment yields intensity in Wei River basin. Research of Soil and Water Conservation 11(4): 60-63.

Lane SN, Tayefi V, Reid S, Yu D, Hardy R. 2007. Interactions between sediment delivery, channel change, climate change and flood risk in a temperate upland environment. Earth Surface Processes and Landforms 32(3): 429-446.

Lecce SA, Pease PP, Gares PA, Wang J. 2006. Seasonal controls on sediment delivery in a small coastal plain watershed, North Carolina, USA. Geomorphology 73(3-4): 246-260.

López-Tarazón JA, Batalla RJ, Vericat D, Francke T. 2012. The sediment budget of a highly dynamic mesoscale catchment: the River Isábena. Geomorphology 138: 15-28.

Mackin JH. 1948. Concept of the graded river. Geological Society of America Bulletin 59(5): 463-512.

Mather AE. 2000. Adjustment of a drainage network to capture induced base-level change: an example from the Sorbas Basin, SE Spain. Geomorphology 34(3-4): 271-289.

Meade RH, Moody JA. 2010. Causes for the decline of suspendedsediment discharge in the Mississippi River system, 1940-2007. Hydrological Processes 24: 35-49. 
Meade RH, Parker R. 1985. Sediment in Rivers of the United States. US Geological Survey Water-Supply Paper 2275: 49-60.

Owens PN, Petticrew EL, van der Perk M. 2010. Sediment response to catchment disturbances. Journal of Soils and Sediments 10(4): 591-596.

Ran DC. 2006. Water and sediment variation and ecological protection measures in the middle reach of the Yellow River. Resource Science 28(1): 93-100.

Ran L, Lu X, Xin Z. 2014. Erosion-induced massive organic carbon burial and carbon emission in the Yellow River basin, China. Biogeosciences 10(8): 945-959.

Reid SC, Lane SN, Berney JM, Holden J. 2007. The timing and magnitude of coarse sediment transport events within an upland, temperate gravel-bed river. Geomorphology 83(1): 152-182.

Schumm S. 1993. River response to base level change: implications for sequence stratigraphy. The Journal of Geology 101(2): 279-294.

Shi C. 2005. Causes for continuous siltation of the lower Yellow River. Geomorphology 68(3-4): 213-223.

Shi H, Shao M. 2000. Soil and water loss from the Loess Plateau in China. Journal of Arid Environments 45(1): 9-20.

Slattery MC, Phillips JD. 2011. Controls on sediment delivery in coastal plain rivers. Journal of Environmental Management 92(2): 284-289.

Slaymaker O. 2003. The sediment budget as conceptual framework and management tool. Hydrobiologia 494: 71-82.

Sun J, Xu L. 2007. River terraces in the Fenwei Graben, central China, and the relation with the tectonic history of the India-Asia collision system during the Quaternary. Quaternary Science 27(1): 20-26.

Syvitski JPM, Peckham SD, Hilberman R, Mulder T. 2003. Predicting the terrestrial flux of sediment to the global ocean: a planetary perspective. Sedimentary Geology 162: 5-24.

Syvitski JPM, Vörösmarty CJ, Kettner AJ, Green P. 2005. Impact of humans on the flux of terrestrial sediment to the global coastal Ocean. Science 308(5720): 376-380.

Tarras-Wahlberg NH, Lane SN. 2003. Suspended sediment yield and metal contamination in a river catchment affected by El Niño events and gold mining activities: the Puyango River Basin, southern Ecuador. Hydrological Processes 17: 3101-3123.

Trimble SW. 1999. Decreased rates of alluvial sediment storage in the Coon Creek Basin, Wisconsin, 1975-1993. Science 285: 1244-1246.
Trimble SW. 2009. Fluvial processes, morphology and sediment budgets in the Coon Creek Basin, WI, USA, 1975-1993. Geomorphology 108: 8-23.

Walling DE. 1983. The sediment delivery problem. Journal of Hydrology 65: 209-237.

Walling DE. 2006. Human impact on land-ocean sediment transfer by the world's rivers. Geomorphology 79: 192-216.

Walling DE, Collins AL. 2008. The catchment sediment budget as management tool. Environmental Science and Policy 2: 136-143.

Walling DE, Fang D. 2003. Recent trends in the suspended sediment loads of the world's rivers. Global and Planetary Change 39(1): 111-126.

Walter RC, Merritts DJ. 2008. Natural streams and the legacy of waterpowered mills. Science 319(5861): 299-304.

Wang Z, Li C, Wang F. 2004. Effect of Tongguan's elevation on the fluvial process of the lower Weihe River. Journal of Hydraulic Engineering 9: 1-8.

Wang G, Wu B, Wang Z. 2005. Sedimentation problems and management strategies of Sanmenxia Reservoir, Yellow River, China. Water Resources Research 41(9): W09417. DOI: 10.1029/2004WR003919

Wang Z, Wu B, Wang G. 2007. Fluvial processes and morphological response in the Yellow and Weihe Rivers to closure and operation of Sanmenxia Dam. Geomorphology 91: 65-79.

Wang H, Yang Z, Saito Y, Liu JP, Sun X, Wang Y. 2007. Stepwise decreases of the Huanghe (Yellow River) sediment load (1950-2005): impacts of climate change and human activities. Global and Planetary Change 57(3): 331-354.

Wang H, Yang GL, Wang RF. 1994. Analysis and calculation for effect of engineering measure on sediment and runoff in Weihe Watershed. Bulletin of Soil and Water Conservation 14(5): 48-52.

Wu B, Wang G, Wang Z, Xia J. 2004. The effect of water discharge and sediment load on Tongguan elevation and its changing dynamics. Chinese Science Bulletin 49(14): 1461-1465.

Xu J. 2000. Grain-size characteristics of suspended sediment in the Yellow River, China. Catena 38(3): 243-263.

Zhang Q, Xu C, Becker S, Jiang T. 2006. Sediment and runoff changes in the Yangtze River basin during past 50 years. Journal of Hydrology 331(3): 511-523. 